\title{
Teaching Strategy on Learning of English Phrasal Verbs by Economics Major Students in Russia
}

\author{
Dinara G. Vasbieva
}

\section{DOI: 10.18355/XL.2015.08.03.57-65}

\begin{abstract}
The article investigates research into the use of the lexical set strategy for teaching phrasal verbs in Russia. Even though the incidence of phrasal verbs is significant in English-speaking countries, little has been written about other causes of the non-use of the forms of PVs except for avoidance. Accordingly, this study explored 304 PVs used in 70 talks by Economics Major students. Most of these verbs (83.91\%) were correctly produced, which shows that PVs are not problematic as they are portrayed in previous studies. The author comes to the conclusion that a well-defined strategy for teaching and learning PVs promotes the development of students' foreign language communicative competence.
\end{abstract}

Key words

phrasal verbs, foreign language teaching, communicative competence, idiomatic expression, literal meaning, figurative meaning, idiomatic meaning

\section{Introduction}

Recently there has been an unprecedented demand for and a great diversification in higher education, as well as an increased awareness of its vital importance for sociocultural and economic development of the country, and for building and strengthening good business relationships with foreign partners, for which the younger generations will need to be equipped with new skills, knowledge and expertise. Therefore, higher education is faced with challenges and difficulties relating to equity of conditions at access into and during the course of studies, improved staff development, skills-based training, enhancement and preservation of quality in teaching, research and services, relevance of programmes, employability of graduates, establishment of efficient co-operation agreements and equitable access to the benefits of international co-operation (http://www.unesco.org/education/educprog/ wche/declaration_eng.htm\#world\%20declaration). Globalization of the world economy contributes to the development and improvement of the quality of foreign language training at the level approaching the communicative competence of an educated native speaker (Kalugina, 2014). As a result, a priority is teaching foreign language for specific purposes.

However, professional communicative competence of Economic Major students through learning foreign languages means understanding lexical units and formal rules regarding their use in speech as well as knowledge of an idiomatic expression (an idiom). It is an expression, word, or phrase that has a figurative meaning conventionally understood by native speakers. This meaning is different from the literal meaning of the idiom's individual elements. In other words, idioms don't mean exactly what the words say. To know idioms in a broad sense means to know a word of a foreign language, especially its compatibility with other words and its full semantic structure. (Anichkov, 1947).

Our experience of teaching English in non-language high school shows that students have difficulty mastering lexical units that form the lexical side of foreign speech and are characterized by a particular semantic and structural properties. These semantic units are phrasal verbs (PVs) that generate a large number of speech errors 
and probability of occurrence of communication breakdown due to interlingual and intralingual interference.

\section{Phrasal verbs: definitions and incidence}

The phrasal verbs are relatively unitary combinations of a verb and a particle, which is best of all described as an adverb, not as a preposition. While any kind of lexical verb could theoretically be a part of a phrasal verb, the word following the verb belongs to a relatively closed class of invariable items. The following list of items can be used as particles:

aback, aboard, about, above, across, after, ahead, along, apart, around, ashore, aside, astray, asunder, away, back, behind, by, counter, down, forth, forward(s), home, in, off, on out, over, past, round, through, to, together, under, up

The italicized items in the list can be used as prepositions as well, which is the reason why so much trouble is taken in the literature to distinguish phrasal and prepositional verbs. (Claridge, 2000).

Formally speaking, phrasal verbs consist, first of all, of monosyllabic and non-stative verbs of Germanic origin such as break, bring, call, cast, come, cut, do, fall, get, give, go, hang, hold, keep, kick, knock, lay, lie, live, look, make, move, pass, play, pull, push, put, run, send, set, sit, stand, stay, stick, take, talk, throw, turn and adverbial particles aback, about, above, across, after, against, ahead, along, among, apart, around, as, aside, at, away, back, before, behind, below, beneath, between, beyond, by, down, for, forth, forward, from, in/into, of, off, on/onto, out, over, overboard, past, round, through, to, together, towards, under, up/upon, with, without (Sinclair, 2002).

Their major characteristic is that they combine into units where the elements have given up their individual meanings to form a single lexical word (Bolinger, 1971:xii). Many adverbial particles, according to O'Dowd (1998:18-19), have a corresponding preposition. This idea will be best illustrated on the basis of two entries from Cowie and Mackin's phrasal verb dictionary. The verb look up has four different meanings and four different syntactic patterns (cf. Cowie and Mackin [1975] 1978:196-197).

As an intransitive combination with the particle as preposition, look up denotes either raise one's eyes or improve, for instance:

(1) a. He didn't look up from his newspaper when I entered the room.

b. Prospects for the small builder are looking up. (Cowie and Mackin [1975] 1978:196)

As a transitive combination with the particle in adverbial function, look up denotes either to search information about something or to search for somebody's home so as to visit him:

(2) a. He comes back with an enormous dictionary, sits down and looks up the word.

b. I've promised that the next time I go to London I'll look him up. (Cowie, Mackin [1975] 1978:196-197)

Phrasal verbs cover both the literal and figurative/idiomatic uses. Grammarians who take this position classify phrasal verbs based on their use in sentence patterns (syntactical properties) and as new word formations (morphological properties), as well as by the overall meaning of these verb combinations (semantic properties). The examples below illustrate the same phrasal verb having both a literal and figurative meaning.

She put down the book. (literal)

The army put down the rebellion. (figurative/idiomatic) 
Phrasal verbs may be intransitive: The party broke up when we turned in, or transitive: She put the heckler down. She put down the heckler. In the case of an object (noun) receiving the action of the verb, the object may come before or after the particle.

If the object is a pronoun, it comes between the verb and particle: She put him down, not *She put down him.

Most of the common phrasal verb particles are - in their basic meanings words which describe positions in space: up, down, in, out, on and off all have literal uses that relate to 'spatial orientation'. Many of these concepts also have figurative uses which are found in many languages: for example, the ideas of being 'up' or 'down' are often equated metaphorically with quantities and with power. If an amount goes up it becomes larger, if it goes down it becomes smaller. Similarly, people in powerful positions are thought of as being 'high up', whereas the weak and powerless are 'down at the bottom'. As Moon explains, these progressions from literal to metaphorical are by no means arbitrary, but are rooted in our physical experiences in life: "The idea 'up/high' refers to large quantities because when more things are added to a pile, it becomes higher; and the idea 'up/high' refers to being powerful because if two people fight and one of them is physically on top of the other, that person usually wins". (Moon, 2005)

We can see here the beginnings of a fairly systematic process, in which the basic, 'spatial' particles develop new and more abstract meanings. As these particles combine with common verbs to form phrasal verbs, the metaphorical meanings of the particles contribute to our understanding of the whole phrasal verb. Thus, when someone leaves a powerful position, we say they step down, or if a dictator is removed from office he is brought down. In each case, we can see that the choice of particle is not at all arbitrary: it is the particle down - with its association with loss of power - which gives us the best clue to the meanings of the phrasal verb (Macmillan English Dictionary, 2002; Macmillan Phrasal Verbs Plus, 2005).

Phrasal verbs are extremely common, especially in spoken English, and are used more informally than their Latinate synonyms, e.g. use up vs. consume; gather together vs. assemble; put out vs. extinguish. English grammarians note that phrasal verbs have increased significantly since the mid-nineteenth century and especially so in mid-twentieth century American English. Many phrasal verbs can be replaced, with little change of meaning, by single word verbs: give in by yield, look after by tend, carry on by continue, put up with by tolerate. In most cases the phrasal verb is less formal, more colloquial and more image-and/or emotion-laden than the single word. Phrasal verbs and their noun derivatives account for a significant number of new words now being coined in the English language.

Phrasal Verbs (PV) are a peculiarity of the family of Germanic languages. In the case of English, these verbs seem to occur, on the whole, more frequently in spoken than in written language (Liao and Fukuya, 2004). Furthermore, some research has suggested that PVs are "usually used informally in everyday speech as opposed to the more formal Latinate verbs" (Long and Summers, 1979). Thus, the semantic acceptability of this verbal structure is relative to the type of language output produced by English native speakers. In other words, it seems that PVs are widely accepted by native speakers only during spoken communication. For instance, the verb "to get together" could be, on a regular basis, more accepted/used in everyday speech than "to congregate", which appears to be reserved for written/formal language.

However, there are some PVs that are essentially non-idiomatic in nature; therefore, their meaning may be easily deduced if the verb components are known by the learner. For instance, if the meaning of rush or steam is well known, it would not be a problem, for the listener, to understand verbs such as rush away or steam off. 
These PVs are called Literal phrasal verbs, since their meaning is a straightforward product of their own semantic components (McCarthy and O'Dell, 2004). Phrasal verbs are combinations of words that perform the function of a verb. These combinations necessarily include a verb, and either/both an adverb or a preposition (Long and Summers, 1979). Therefore, PVs form one complete semantic unit because the words that comprise them together describe just one action. However, some PVs share no similarity with other single verbs that represent the same action (synonyms). This type of PVs is called idiomatic phrasal verbs, since they are commonly used in informal-everyday speech. On the other hand, most of these verbs are an integral part of the language of newspapers, law and Economics due to the gradual transition of the majority of PVs from one stylistic layer to another, by borrowing new meanings and losing the old ones. Some phrasal verbs, as opposed to the regular verbs which are their synonyms, are common in professional speech.

In present-day English language, which is a dynamic and evolving system, particles are part of the most combinations of different types. It is important to emphasize a steady increase in combinations of a verb and adverbial particle in English from the beginning of the Early Modern English period to the present, as evidenced by the great variety of books, dictionaries, grammar reference books devoted to phrasal verbs and their use. There is a direct correlation between the number of combinations and frequency of their use. Therefore, phrasal verbs perform an essential function due to the greater succinctness and at the same time more expressive coloring.

It should be noted that phrasal verbs are widely used in the language of mass media due to their simplicity, vividness, force and neatness. However the heterogeneity of the use of PVs in stylistic is evidence of their low prevalence in the economic literature. For example, in Market Leader Intermediate Business Course book by D. Cotton, D. Falvey, S. Kent used in language teaching process at Financial University, the article «UK develops taste for fair trade» (3200 characters) contains 6 phrasal verbs: phase out - to gradually stop using or providing something; break into to become involved in a new job or business; share out - to divide something between two or more people; deal with - to do business with someone or have a business connection with someone; grow into - to develop over time and become a particular kind of person or thing; put into - to make money available to be used for a particular purpose. There are 5 phrasal verbs in the article «Inside Procter and Gamble innovation machine» (4500 characters): put out - to produce something for people; cut down - to reduce the amount of something; roll out - to expand; report to - to be responsible to someone at work and be managed by them; give out - to give something to each person in a group.

So, we can see that phrasal verbs do not have expressive coloring in the economic texts. The language of economics does not need vividness and expressiveness. Therefore, the above phrasal verbs are associated with clarity and succinctness. We have also examined several economic texts and articles from the Business Benchmark Upper Intermediate Course book by Guy Brook-Hart where the number of phrasal verbs is also small. (1 phrasal verb on average per $600-700$ characters). Here are some examples:

a) A radio advertising compaign and online publicity called for young men

to $\log$ on to the Internet to play a video game on the AXE website. (= to meet someone at their home in order to take somewhere).

b) At the launch of Denizen, its low-cost brand, in India, Levi's has brought in what they call the «Denizen 8 », a team consisting of a software developer, a media planner, a property consultant, an app developer, a writer and a 
student, all aged between 18 and 28. (= to ask someone to become involved in a discussion or situation).

c) But the major problem was raising finance and setting up a production facility. (= to prepare the equipment that will be needed for an activity so that it is ready to be used).

d) Since then, Drink Me Chai has taken up by Waitrose, another supermarket chain. (= to accept a suggestion, offer, or idea).

As noted above, in most cases interpreting the meaning of the phrasal verb is not limited to one word, it is often a phrase or a sentence. The choice of these PVs is explained by the need in accuracy and succinctness.

Most phrasal verbs have the meaning similar to the dictionary entry (i.e. without obtaining new meanings in the economic literature) and have no stylistic coloring, for example: The new warehouses are equipped with all the latest technology (= to have). An effective advertising campaign should focus upon a sales pitch and direct mail (= to pay attention). These verbs can be used in both everyday speech and formal business speech. PVs in economic texts and articles have narrow, special meanings only in some cases, so their meanings are very diverse.

Economic texts and articles, containing phrasal verbs and idiomatic expressions enrich students' vocabulary, develop their skill to recognize and produce them in the fields of business communication such as meetings, presentations, negotiations, telephone conversations (Vasbieva, Slukina, 2014).

\section{Difficulties and Problems in Acquisition of Phrasal Verbs}

Despite the growing number of publications devoted to these lexical and grammatical phenomena, the use of PVs and their lexical features cause a lot of problems. Furthermore, most linguists share the opinion that phrasal verbs constitute one of the most distinctive and creative features of the modern English language. In addition, PVs are always of great importance in the English lexicon. A significant increase in the number of phrasal verbs along with the regular phrases and nominative complex expressions contribute to a rise in degree of idiomatic English.

From the perspective of a learner of English as a foreign language (EFL), PVs are not only an important feature of English grammar whose degree of mastery reveals the command of lexicon and style. But, due to their heterogeneity and complexity, they are difficult to master and provide a vast potential for mistakes but they are also very complex and heterogeneous. According to Darwin and Grey (Darwin and Grey, 1999), many particle verbs have entirely idiomatic meaning although both parts of the construction seem very familiar to the learners. This idiomaticity leads to avoidance or to errors because phrasal verbs constitute "a syntactic [and semantic] oddity in the language" to include the quotation by Darwin and Gray (Darwin and Grey, 1999). This is also the reason why phrasal verbs are difficult to describe.

The most difficult thing about phrasal verbs is that in addition to a single literal and/or figurative meaning, some phrasal verbs can have a multitude of different meanings depending on the context. For example, here are some of the many ways in which the phrasal verb pick up is currently used:

1. The phone rang and I picked it up. (to lift something up)

2. He picked her up from the airport. (to take on)

3. She picked up a little Italian during her holiday in Rome. (to acquire knowledge or learning)

4. My daughter picks up her room after school. (to tidy up)

5. He picked up this watch on sale. (to acquire casually)

6. He picked up his package at the post office. (to claim)

7. He picked up some flowers on his way home. (to buy)

61 
8. Her boss picked up the tab for lunch. (to pay a bill)

9. He picked up a virus on his trip. (to come down with a disease)

10. The home team picked up eight yards on the play. (to gain)

11. He picked up a date at the singles bar. (to make casual acquaintance)

12. The police picked up the bank robber. (to take into custody)

13. The police dog picked up the scent of the kidnapper. (to come upon and follow)

14. The lawyer picked up his argument after the noon recess. (to continue after a break)

15. The company's sales always pick up around the holidays. (to improve)

16. She just picked up and left home. (to pack one's belongings)

17. We sold our red pickup last year. (noun derived from the verb--a type of truck)

Some linguists say that a phrasal verb is always idiomatic and the meaning cannot be understood by knowing the meaning of the individual words. I think it's more useful to say that some phrasal verbs are easy to guess from the context and others are much more difficult.

\section{Data Collection and Analysis}

Seventy Russian speaking second-year full-time students studying International Finance at Financial University under the Government of the Russian Federation took part in the study. The subjects had already had twelve years of formal instruction in EFL at the rate of about four hours per week at a secondary school and university. To ascertain the acquisition of PVs, causes of under-representation of PVs and effects of avoidance behaviour in EFL learning by the undergraduate students, the present researcher arranged a speaking activity in the light of her own teaching experience and findings of the previous studies conducted with EFL students from different linguistic backgrounds (Liao and Fukuya, 2004, Kharitonova, 2013, Redmond, 2013, etc) as well. The students were given topics as part of weekly assignments of speaking activity. They were asked to speak on one of the following topics of their own choice:

1. A foreign company is opening a branch in your country. What factors should it consider?

2. Companies should be fully involved in the lives of their employees.

3 . How do you think your career will develop in the future?

The students' answers were recorded and then summarized. The data collected were scored by hand.

The figures were summarized in the following table.

\begin{tabular}{|l|c|c|c|c|c|c|}
\hline \multirow{2}{*}{ Type of PVs } & \multicolumn{2}{|c|}{ Used } & \multicolumn{2}{c|}{ Correct } & \multicolumn{2}{c|}{ Incorrect } \\
\cline { 2 - 7 } & No & $\%$ & No & $\%$ & No & $\%$ \\
\hline Non-Idiomatic & 261 & 85.86 & 219 & 83.91 & 42 & 16.09 \\
\hline Idiomatic & 43 & 14.14 & 32 & 74.42 & 11 & 25.58 \\
\hline Total & 304 & 100 & 251 & 82.57 & 53 & 17.43 \\
\hline
\end{tabular}

Table 1: Phrasal Verbs Used in 70 Talks

The table shows a breakdown of the types of phrasal verbs used by the students in their talks. A total of 304 phrasal verbs were used in 70 talks (i.e. about 4 phrasal verbs per talk), $219(83.91 \%)$ being correct and $32(74.42 \%)$ being incorrect. Interestingly, however, the largest number of PVs were non-idiomatic phrasal verbs $(85.86 \%)$, correct non-idiomatic phrasal verbs $(83.91 \%)$ being far more than incorrect 
ones $(16.09 \%)$. In contrast, the percentage of idiomatic phrasal verbs was low $(14.14 \%)$, which proves that they were missing in some talks.

The data collected for this study indicates that the students did use phrasal verbs in their talks and most of them were correct (83.91\%). However, the students used six times the number of non-idiomatic phrasal verbs $(85.86 \%)$ as idiomatic ones (14.14\%). I totally agree with Abdulmoneim Mahmoud (Mahmoud, 2015) that "researchers need differentiate between the two types of PVs and show the magnitude of the problem in each type" as our results of speaking activity (giving talks) are consistent with those of Mahmoud's. Researchers Liao and Fukuya and Kharitonova attribute under-representation of phrasal verbs to 'avoidance'. However, it is difficult to differentiate avoidance from ignorance even if a student uses a single word (e.g. stop) rather than a phrasal verb (give up). The non-use of phrasal verbs by EFL students needs explaining carefully. The reasons for this might be as follows:

- lack of knowledge

- incomplete learning

- ignorance and passive learning for comprehension

- a strategy used to avoid errors such as the use of the wrong verb or leaving out or wrong order of the particle

- use of alternative language forms.

The under-representation of phrasal verbs in speaking is as normal as the lack of knowledge of any single-word vocabulary items. Avoidance of phrasal verbs is considered to be a communication strategy to avoid errors. Besides, avoidance does not necessarily lead to an error. It is no use blaming EFL learners for using alternative language forms to express their ideas. Thus, the students might have avoided the possible phrasal verb errors due to the above reasons.

On the other hand, phrasal verbs help EFL learners develop fluency and spontaneity in speech and in writing as well. So there is a need for devising an effective teaching strategy on learning PVs by EFL students.

\section{Teaching Strategy}

Perhaps the most effective strategy is to learn PVs one at a time. Students should try to memorize them and use them more frequently in speaking and writing activities. It is difficult to learn a large number of idioms at once. It is a good idea to remember them upon consideration. For example, if an idiomatic expression is given in the text, students are encouraged to underline it or note it down, check its meaning in a good dictionary and give their own examples based on their personal life or their interests. They can do this by adapting the definition in the dictionary.

From the point of view of difficulties and problems in acquisition of semantic and collocational features of phrasal verbs, it is obvious that such verbs should be regarded as phrases with syntactic and contextual features, rather than individual words. Forcing students to learn by heart phrasal verbs is a thing of the past. The corpus-based study of PVs clearly reveals the need for contextualized approach based on (semi-) authentic texts, because it will enable the teacher to draw students' attention to the widespread use of PVs in spoken or written language, the syntax of phrasal verbs and the word they join.

It is essential to take into account the students' mother tongue while teaching English phrasal verbs, particularly:

- If the students' mother tongue does not contain phrasal verbs with adverbial particles, the teacher should spend more time teaching PVs so that the students become familiar with this phenomenon; 
- If the students' mother tongue includes phrasal verbs with adverbial particles, the teacher should draw students' attention to any stylistic differences between phrasal verbs of their native language and English phrasal verbs;

- it is important to draw students' attention to any differences between the phrasalprepositional verbs of their native language and similar English phrases.

Teaching phrasal verbs to EFL students should be purposeful, as phrasal verbs are an important means of developing students' communicative skills by using idioms and getting students to be familiar with the methods of formation and expression of thoughts by native speakers.

Learning phrasal verbs can improve and expand students' vocabulary provided that the linguistic features of these lexical units and common errors are analyzed carefully to cope with difficulties acquiring PVs.

It is important to select phrasal verbs in accordance with the communicative goals at a certain stage of the teaching process, taking into account cultural values, cross-cultural differences and, following the lexical and statistical principles of selection of words based on their frequency of use. Using authentic texts consistent with the objectives of formation of students' communicative competence is crucial.

\section{Conclusion}

Phrasal verbs are most dynamic, productive, semantically rich group of English verb lexicon. Phrasal verbs are especially useful in the quest to reach fluency in English - this type of language will not only make students sound natural (more like a native speaker) but very often it will also allow them to be more efficient with the foreign language. Phrasal verbs are efficient because they 'say' a lot. They contain a lot of meanings.

Thus, the level of development of Economic Major students' foreign language competence depends on their skills and abilities to use the productive vocabulary in speech for implementing communication tasks in the professional sphere.

\section{References}

ANICHKOV, I.E. 1947. Angliyskiye Adverbial'nye Poslelogy. Text: diss. doct. filol. nauk/ I.E. Anichkov. M. 342 p. AVDEVICH, N.V. 2007. Kognitivno-diskursivnye osobennosti mnogoznachnyh frazovyh glagolov $\mathrm{v}$ sovremennom angliiskom yazyke Diss. Moskva: MGLU. Available at <http://cheloveknauka.com/kognitivnodiskursivnye-osobennosti-mnogoznachnyh-frazovyh-glagolov-v-sovremennomangliyskom-yazyke\#ixzz3V82s2oQZ>

BOLINGER, D. 1971. The Phrasal Verb in English. Cambridge, Mass.: Harvard University Press.

BROOK-HART, G. 2013. Business Benchmark. Upper Intermediate. 2nd edition. Student's book without keys with Audio CD. Cambridge University Press.

CLARIDGE, C. 2000. Multi-Word Verbs in Early Modern English: A Corpus-Based Study. ISBN 978-904200449-8

COTTON, D. - FALVEY, D. - KENT, S. 2005. Market Leader: Intermediate Business English Course Book. Pearson Educated Limited.

COWIE, A.P. 1978. The place of Illustrative Material and Collocations in the Design of a Learner's Dictionary.

COWIE, A.P. and MACKIN, R. 1975. Oxford Dictionary of Current Idiomatic English Vol 1. Oxford: Oxford University Press.

DARWIN, C., and Gray, L. 1999. Going after the Phrasal Verb: An Alternative Approach to Classification. TESOL Quarterly, pp. 65-83. 
KALUGINA, O.A. 2014. Portfolio as the Technology of Forming the ProfessionalCommunicative Competence of Students. Science Review: Humanities Research N 10, 2014, pp.24-27.

KHARITONOVA, A. 2013. Lexical transfer and avoidance in the acquisition of English phrasal verbs. MA Thesis, University of Oslo.

LIAO, Y. - FUKUYA, Y. J. 2004. Avoidance of Phrasal Verbs: The Case of Chinese Learners of English. Language Learning, pp. 193- 226.

LONG, T. - SUMMERS, D. 1979. Longman Dictionary of English Idioms: Longman Group Limited: Mahwah, NJ: Routledge. 457p.

MACMILLAN ENGLISH DICTIONARY. 2002. Macmillan Publishers Limited. Bloomsbury Publishing Plc. ISBN 9781405025263

MACMILLAN PHRASAL VERBS PLUS. 2005. Macmillan Publishers Limited. Bloomsbury Publishing Plc. ISBN 9781405063906

MAHMOUD, A. 2015. Under-representation of Phrasal Verbs in EFL University Students' Free Writing. International Journal of English and Education. Volume 4, Issue 1, pp. 263-265. ISSN 2278-4012

McCARTHY, M. - O'DELL, F. 2004. English phrasal verbs in use. Cambridge: Cambridge UP. ISBN 0521527279

MOON, R. 2005. Methaphor and Phrasal Verbs. In: Rundell, Michael (ed.). Macmillan Phrasal Verbs Plus. Oxford: Macmillan. ISBN 9781405063906

O'DOWED, E.M. 1998. Prepositions and Particle: A Discourse-Functional Account. Oxford: Oxford University Press.

REDMOND, L. 2013. Phrasal Verbs and Avoidance in SLA. Available at <http://conference.Pixelonline.net/ICT4LL2013/ common/download/Abstract_pdf> SINCLAIR, J. 2002. Collins Cobuild: Phrasal Verbs Dictionary. Publisher: Collins Cobuild. ISBN 9780007134021

VASBIEVA, D. G. - SLUKINA, G. V. 2014. English Phrasal Verbs as a Means of Development of Students' Cross-Cultural Professional Communicative Competence. In: Fundamental and Applied Research Studies of the Economics Cooperative Sector, №1, January-February 2014, pp. 207-211. ISSN 2076-9288

WORLD Declaration on Higher Education for the Twenty-First Century: Vision and Action. 1998. World Conference on Higher Education. Available on the internet: <http://www.unesco.org/education/educprog/wche/declaration_eng.htm\# world\%20declaration>.

Words: 4716

Characters: 29873 (16,60 standard pages)

Assoc. Prof. Dinara Giniyatullovna Vasbieva, PhD.

Department "Foreign Languages - 4"

Finance University under the Government of the Russian Federation

Leningradsky prospect 49

125993 Moscow

Russia

dinara-va@list.ru 